University of Nebraska - Lincoln

DigitalCommons@University of Nebraska - Lincoln

Community and Regional Planning Program:

Faculty Scholarly and Creative Activity

Community and Regional Planning Program

2008

\title{
Evaluating California Local Land Use Plan's Environmental Impact Reports
}

Zhenghong Tang

University of Nebraska - Lincoln, ztang2@unl.edu

Elise Bright

Texas A\&M University, College Station, TX

Samuel Brody

Texas A\&M University, College Station, TX

Follow this and additional works at: https://digitalcommons.unl.edu/arch_crp_facultyschol

Part of the Urban, Community and Regional Planning Commons

Tang, Zhenghong; Bright, Elise; and Brody, Samuel, "Evaluating California Local Land Use Plan's Environmental Impact Reports" (2008). Community and Regional Planning Program: Faculty Scholarly and Creative Activity. 4.

https://digitalcommons.unl.edu/arch_crp_facultyschol/4

This Article is brought to you for free and open access by the Community and Regional Planning Program at DigitalCommons@University of Nebraska - Lincoln. It has been accepted for inclusion in Community and Regional Planning Program: Faculty Scholarly and Creative Activity by an authorized administrator of DigitalCommons@University of Nebraska - Lincoln. 


\title{
Evaluating California Local Land Use Plan's Environmental Impact Reports
}

\author{
Zhenghong Tang, ${ }^{a}$ Elise Bright, ${ }^{\mathrm{b}}$ and Samuel Brody ${ }^{\mathrm{b}}$ \\ ${ }^{a}$ Community and Regional Planning Program, 302 Architecture Hall, University of Nebraska-Lincoln, Lincoln, NE 68588-0105, USA \\ ${ }^{\mathrm{b}}$ Department of Landscape Architecture and Urban Planning, Texas A\&M University, College Station, TX, 77843-3137
}

Corresponding author - Z. Tang, email zhenghongtang@hotmail.com or ztang2@unl.edu

\begin{abstract}
Local land use planning has profound impacts on environmental quality; however, few empirical studies have been conducted to systematically measure local land use plans' environmental assessment quality and to identify the factors influencing it. This paper analyzes the quality of 40 Environmental Impact Reports (EIRs) of local jurisdictions' land use plans in California. A plan evaluation protocol defined by five core components and sixty-three indicators is developed to measure the quality of local land use plans' EIRs. The descriptive results indicate that the local jurisdictions produce relatively good quality on its EIRs, but there is still much room for improvement. There are large variations in the quality of EIRs across local jurisdictions. The regression results further highlight three major factors that can significantly influence local land use plan's EIR quality: number of planners, plan updating ability, and development pressure.
\end{abstract}

Keywords: environmental assessment, environmental impact reports, land use planning, quality, local jurisdictions, California

\section{Introduction}

Local land use planning has profoundly impacted environmental resources, species, ecosystems, air, water, human safety, and ultimately the quality of the human environment. A local land use plan serves as the "constitution for future development" since it covers a local jurisdiction's entire planning area, addresses the broad range of development issues, expresses the community's development goals, and embodies public policy relative to the distribution of future uses. Many studies have increased the awareness of the fact that local land use planning has a significant effect on regional and national environment quality (Bonnell and Storey, 2000; Pendall, 1998; Jones et al., 2005).

California has recently paid special attention to integrate environmental impact assessment with local land use plans. According to California Environmental Quality Act (CEQA) and California General Plan Guidelines, environmental impact reports (EIRs) must be conducted for local land use plans as an integral part of the planning process (CEQA, 2006; California Office of Planning and Research, 2005). Although great progress has been made in California, many crucial problems are still unsolved in the practice of local land use planning and environmental assessment. These include: What critical components are needed in a local land use plan's environmental assessment? How can we quantitatively measure the quality of environmental assessment? What factors influence the quality of a local plan's environmental assessment? How can we do better for local land use plan's environmental assessment?
The objective of this study is to evaluate the quality of local land use plan EIRs and then identify the factors influencing the quality of local land use plan EIRs. Specifically, this study answers the following three research questions: 1) How well do local jurisdictions in California develop high quality EIRs for local land use plans? 2) Which factors influence the quality of local land use plan EIRs? 3) How can local planning process be improved to enhance EIRs' quality and effectiveness? The conceptual model is developed to measure the EIR quality and to identify the factors influencing it (Fig. 1).

Based on this conceptual model, this study first conceptualizes the quality of local land use plans' EIRs, and then analyzes four sets of major factors influencing the quality.

\section{EIR quality evaluation criteria}

Evaluating environmental assessment quality refers to determinants of quality in aspects of environmental assessment's institutional arrangements, procedures, methods, and outcomes (Therrien-Richards, 2000). The European Commission developed a "Guidance on EIA-EIS Review" with a checklist to measure environmental assessment quality (Office for Official Publications of the European Communities, 2001). In the U.S., evaluation guidance was also developed to guide the reviewing of documents prepared under the National Environmental Quality Act (CEQ, 1997).

The most common approach for evaluating environmental assessment quality is using the checklist system. Gray and Edwards- 


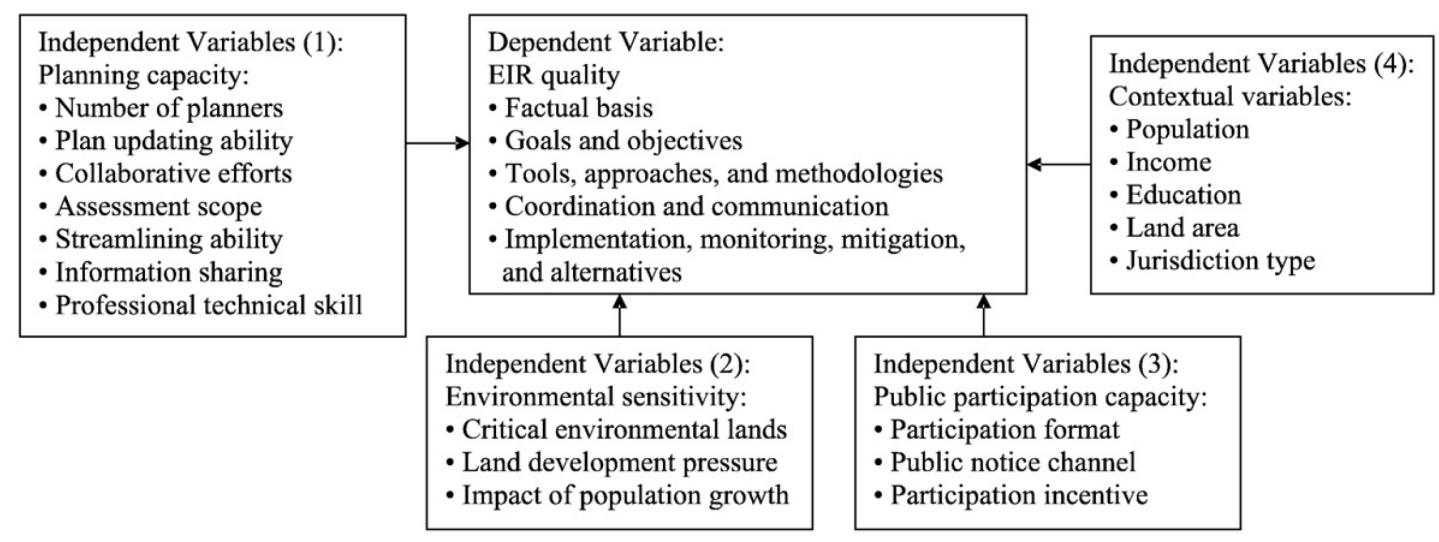

Figure 1. Conceptual model.

Jones (1999) developed a grading system to evaluate environmental assessment quality in the Scottish forest sector. Fischer (2002) and Canelas et al. (2004) evaluated the quality of environmental impact statements based on the evaluation indexes. Tzoumis and Finegold (2000) and Tzoumis (2007) adopted a similar rating system to analyze the quality of draft environmental impact statements in the United States over time. Noble (2004) discussed strategic environmental assessment quality assurance and emphasized improving the consistency of judgments in assessment panels. Jones et al. (2005) make an international evaluation review for land use plan quality and effectiveness from a strategic environmental assessment perspective across different countries and planning systems.

This study further develops previous environmental assessment quality systems by conceptualizing an evaluation framework consisting of five core components that measure the quality of EIRs for local land use planning. These five components include: 1) factual basis, 2) goals and objectives, 3) tools, approaches, and methodologies, 4) coordination and communication, and 5) implementation, monitoring, mitigation, and alternatives. The following section explains the evaluation criteria for each of the five components.

\subsection{Factual basis}

The factual basis of a local land use plan's EIR refers to an understanding of environmental conditions that are closely related to humans and local development. The factual basis of EIR for a local land use plan includes an inventory of existing conditions for the natural environment, built environment, and human health within the targeted jurisdiction. The factual basis should capture the crucial environmental conditions that significantly affect the quality of the human environment in the local development process.

In general, the natural environment is closely related to natural resources conservation and natural environmental protection. There are three types of important environmental issues to consider in the natural environment. First, a solid factual basis of local land use plans' EIRs must identify local jurisdictions' basic environmental conditions. A local land use plan's EIR must have geographic comprehensiveness and identify a local jurisdiction's physical setting and sphere of influence which covers the entire planning area and addresses the broad range of issues associated with development. In addition, major environmental laws and regulations should be identified as a legal base in the environmental assessment processes. Second, a solid factual basis must identify critical local or regional environmental elements including ecosystem, fauna, flora, biodiversity, environmentally sensitive lands, air, and water resources. The connectivity and interaction of these natural systems should also be identified in EIRs. Third, a high quality EIR must identify critical environmental issues at a larger scale such as greenhouse gas emission and climate change, and ozone layer depletion.
Effects on the built environment include considering the environmental values of historic and cultural resources, open spaces, agricultural resources, population and housing impacts, recreation, utilities and public services. Furthermore, an appropriate description of land use patterns and land availability in local development is the foundation of environmental management.

The effects on human health involve the risk of damage from natural disasters; risk of exposure to hazardous materials wastes; and activities; and risk of contracting diseases. Information about environmental hazards and community safety determines the relative suitability of lands for development. Meanwhile, population growth is a critical issue for local development since it increases the demands for resources that are important to quality of life.

\subsection{Goals and objectives}

The goals and objectives of a local land use plan's EIR should be a reflection of the needs and desires of the local jurisdictions as well as an indication of the actions required to achieve the envisioned future for effective environmental assessment. Burby (2005) and Nelson and French (2002) have found that more thorough, clear, specified goals and objectives can subsequently result in formulating and adopting effective strategies. The critical goals in local land use plans' EIRs should include protecting natural resources and environmental values; seeking intergenerational sustainability; and balancing environmental, social and economic development. In addition, local jurisdictions should seek environmental justice and equity in local development. Additionally, local jurisdictions must protect critical environmental resources such as ecosystems, biodiversity, water, land, air, and open space. Finally, goals of local jurisdictions should protect historical and cultural resources and build disaster-resistant, healthy, safe communities.

\subsection{Tools, approaches, and methodologies}

Tools, approaches, and methodologies represent the bridge of an EIR because they are the means for realizing the targeted goals and objectives. Environmental assessment tools have been widely discussed by many researchers (Brown and Therivel, 2000; Kuo et al., 2005; Liou et al., 2006; Verheem and Tonk, 2000; Wrisberg, 2002). CEQ (1997) suggested the primary and special methods for analyzing cumulative effects, including questionnaires, interviews and panels, checklists, matrices, networks and system diagrams, modeling, trends analysis, overlay mapping and GIS. Lawrence $(2003 a, b)$ makes a summary for environmental assessment methods: network analysis and systems diagrams, modeling, projection and forecasting, backcasting, visioning, scenario writing, story telling, ecological footprint analysis, life cycle analysis, rapid rural and participatory rural appraisal. Munier (2004) and Therivel 
(2004) summarize the major tools in environmental assessment. Based on this literature, this study combines the traditional tools with recently developed tools.

\subsection{Coordination and communication}

Coordination and communication is the dominant theory to guide local land use planning and environmental assessment (Richardson, 2005). Inter-organizational coordination and information communication is a key component in defining local EIR quality to manage trans-boundary environmental issues. Coordination and communication identifies the need to coordinate with other agencies, jurisdictions and citizens to make a high quality EIR for local land use planning. Inter-organizational coordination emphasizes that the environmental problems are complex, cross-boundary, dynamic dispersed and multiple-scale. Therefore, effective environmental assessment and management requires a wide range of expertise to understand these environmental problems, and an even wider range of agencies to find and implement solutions. Inter-organizational coordination serves as an umbrella framework for all the agencies providing collaborative services at the local level. Identifying stakeholders and their inter-organizational coordination procedures can help eliminate areas of conflict, identify locations where specific conflicts will occur or attempt to create a mechanism for conflict resolution. Effective communication needs to specify public participation processes and identify effective information accessibility, notification, and dissemination.

\subsection{Implementation, monitoring, mitigation, and alternatives}

An effective EIR for a local land use plan must include a strong element for implementation, monitoring, mitigation, and alternatives that can define a commitment to adjust possible environmental impacts. EIRs should identify the significant irreversible environmental impacts, growth-inducing impacts, cumulative impacts, and impacts found not to be significant in local land use plans. In addition, an EIR should present a reasonable range of alternatives under which most of local land use plan's basic objectives could feasibly be attained. EIRs should involve an implementation commitment to translate the vision, goals, policies, tools and strategies into specific tasks. Thus, they should assign each task to a designated agency within the jurisdiction. The implementation component should have a clear schedule, necessary technical assistance, and identify cost-effective and reliable financial support.

These core components provide a framework to measure the quality of a local plan's EIR. Under this framework, detailed indicators are developed within each component to explain the key points that comprise a strong impact report (Table 1). When aggregated, these indicators can be statistically measured in order to provide a platform to compare the quality of plans across multiple jurisdictions. Within each plan component a detailed set of indicators can be identified, measured, and compared across multiple EIRs.

\section{Factors influencing EIR quality}

Local land use planning and its environmental assessment is a complex process regarding geographic, social and economic settings, which are usually affected by many factors including jurisdiction framework, planners' values and experiences, information resources, and awareness of alternatives. Some recent studies have detected the factors influencing environmental assessment quality. Furman and Hilden (2001) and Hilden et al. (2004) summarized external (e.g. awareness, education) and internal factors (e.g. monitoring, public participation) that can influence environmental assessment effectiveness. Jones et al. (2005) further summarize three sets of factors that are likely to influence the quality of environmental
Table 1. EIR quality evaluation coding protocol

\begin{tabular}{|c|c|c|}
\hline \multicolumn{3}{|l|}{ I. Factual basis } \\
\hline $\begin{array}{l}\text { Local environmental } \\
\text { setting }\end{array}$ & Regulatory setting & Sphere of influence \\
\hline $\begin{array}{l}\text { Ecosystem's concept, } \\
\text { function, process and } \\
\text { integrity }\end{array}$ & $\begin{array}{l}\text { Biodiversity and disturbance } \\
\text { and threats }\end{array}$ & $\begin{array}{l}\text { Water consumption and } \\
\text { water resources availability }\end{array}$ \\
\hline $\begin{array}{l}\text { Water quality and } \\
\text { point/nonpoint-source } \\
\text { pollution }\end{array}$ & $\begin{array}{l}\text { Groundwater supply and } \\
\text { aquifer depletion }\end{array}$ & $\begin{array}{l}\text { Hydrological regimes and } \\
\text { aquatic environment }\end{array}$ \\
\hline $\begin{array}{l}\text { Environmentally } \\
\text { sensitive lands }\end{array}$ & Wetland and watershed & $\begin{array}{l}\text { Natural/urban vegetation } \\
\text { and forestry resources }\end{array}$ \\
\hline $\begin{array}{l}\text { Criteria air pollutants in } \\
\text { the planning area }\end{array}$ & $\begin{array}{l}\text { Greenhouse gas emission, } \\
\text { climate change and variability }\end{array}$ & Ozone layer depletion \\
\hline $\begin{array}{l}\text { Land use patterns and } \\
\text { land availability }\end{array}$ & $\begin{array}{l}\text { Open space, green space, } \\
\text { esthetical or recreational } \\
\text { resources }\end{array}$ & $\begin{array}{l}\text { Critical historical and } \\
\text { cultural }\end{array}$ \\
\hline $\begin{array}{l}\text { Population growth and } \\
\text { carry capacity estimation }\end{array}$ & Noise-sensitive areas & $\begin{array}{l}\text { Social/environment/ } \\
\text { disaster vulnerable } \\
\text { population and places } \\
\text { heritage }\end{array}$ \\
\hline
\end{tabular}

Risk of exposure to hazardous materials, wastes, pollution

II. Goals and objectives

Protect natural resources Maintain intergenerational Land use partitioning Multi-criteria analysis

Cost-benefit analysis Risk or vulnerability environmental impacts

Impacts found not to be Strategic alternatives and environmental sustainability

values

Seek to environmental justice and equity

Achieve sustainable and healthy ecosystems and protect biodiversity

Seek to efficient use of Seek to clear air and climate land and smart growth stability

Value and protect diversity and local distinctiveness/

Build disaster-resistant, healthy, safe community

history/culture

III. Tools, approaches, and methodologies

On-site environmental Environmental threshold

review of significance

Scenario/sensitivity Network and system and

analysis diagram analysis

Environmental modeling Ecological footprint analysis/carry capacity

Checklists /inventory for Matrices for environmental items environmental issues analysis assessment

IV. Coordination and communication

Identify public and Inter-organizational stakeholder concerns coordination (surrounding, regional, state, federal, private, and NGOs)

Specify public participation processes Identify effective information accessibility, notification and dissemination

V. Implementation, monitoring, mitigation, and alternatives Significant irreversible Growth-inducing impacts significant and their effects

Give a clear, reliable time schedule

Identify reliable financial support for implementation

Balance environmental, social, and economic development

Seek to clean and plentiful water resources

Build accessible open/green space and walkable community

Overlay mapping and GIS analysis

Trends analysis

Questionnaires, interviews, panels Life cycle analysis Compatibility appraisal

Specify trans-boundary environmental issues measures
Cumulative impacts

Identify each major agency's responsibilities for implementation Specify environmental monitoring procedures 
assessment procedures and ultimately the effectiveness of environmental assessment of land use plans: system criteria, process criteria, and outcome criteria. Although many studies have discussed the factors influencing land use planning (Forester 1984; Norton, 2005; Brody, 2003a,b,c), little research quantitatively measures the factors influencing environmental assessment quality. This study presents four sets of independent variables that may influence local land use plan's EIR quality (Table 2): 1) planning capacity, 2) public participation capacity, 3) environmental sensitivity, and 4) contextual variables.

Table 2. Independent variables

\begin{tabular}{|c|c|c|}
\hline Variables & Measurement & Sources \\
\hline $\begin{array}{l}\text { Number of } \\
\text { planners }\end{array}$ & The actual number of planners & CAPBOL, 2007 \\
\hline $\begin{array}{l}\text { Plan updating } \\
\text { ability }\end{array}$ & $\begin{array}{l}\text { The actual year of land use plan } \\
\text { element minus } 2007\end{array}$ & CAPBOL, 2007 \\
\hline $\begin{array}{l}\text { Collaborative } \\
\text { efforts }\end{array}$ & $\begin{array}{l}\text { Jurisdictions participating in regional } \\
\text { collaborative planning efforts: other } \\
\text { cities; counties; special districts; regional } \\
\text { planning agencies; other }\end{array}$ & CAPBOL, $2003^{*}$ \\
\hline Assessment scope & $\begin{array}{l}\text { Type of environmental assessment used } \\
\text { for last comprehensive plan update: } \\
\text { master EIR; program EIR; project EIR; EIR } \\
\text { equivalent; other }\end{array}$ & CAPBOL, $2003^{*}$ \\
\hline $\begin{array}{l}\text { Streamlining } \\
\text { ability }\end{array}$ & $\begin{array}{l}\text { Degree of streamlining environmental } \\
\text { assessment: specific plan EIR; tiering } \\
\text { from prior EIR; master EIR; program EIR; } \\
\text { categorical exemptions; statutory } \\
\text { exemptions; other }\end{array}$ & CAPBOL, 2005* \\
\hline $\begin{array}{l}\text { Information } \\
\text { sharing }\end{array}$ & $\begin{array}{l}\text { Jurisdictions that regularly post on a } \\
\text { website any CEQA document for which it } \\
\text { is the Lead Agency: notice of } \\
\text { preparation; EIR; negative declaration; } \\
\text { declaration; other; description of other }\end{array}$ & \\
\hline $\begin{array}{l}\text { Professional } \\
\text { technical skill }\end{array}$ & $\begin{array}{l}\text { GIS data adopted in local land use } \\
\text { planning }\end{array}$ & CAPBOL, $2003^{*}$ \\
\hline $\begin{array}{l}\text { Public participation } \\
\text { format }\end{array}$ & $\begin{array}{l}\text { Workshops; townhall meetings; site } \\
\text { tours; charrettes; other }\end{array}$ & CAPBOL, $2003^{*}$ \\
\hline $\begin{array}{l}\text { Public notice } \\
\text { channel }\end{array}$ & $\begin{array}{l}\text { Internet; publish in a non-English } \\
\text { newspaper; radio/television; mail } \\
\text { beyond required } 300^{\prime} \text { radius; notices } \\
\text { using community organizations; } \\
\text { community newsletters; other }\end{array}$ & CAPBOL, 2003* \\
\hline $\begin{array}{l}\text { Public participation } \\
\text { incentives }\end{array}$ & $\begin{array}{l}\text { Evening meetings; provide daycare; } \\
\text { provide transportation; near the project } \\
\text { site; involve youth; post minutes or } \\
\text { projects on the internet; allow public } \\
\text { comment by E-mail/ internet; use } \\
\text { alternative }\end{array}$ & CAPBOL, 2003* \\
\hline $\begin{array}{l}\text { Critical } \\
\text { environmental } \\
\text { lands }\end{array}$ & $\begin{array}{l}\text { Approximate proportion of jurisdiction } \\
\text { encompassing sensitive natural areas }\end{array}$ & $\begin{array}{l}\text { California spatial } \\
\text { information library }\end{array}$ \\
\hline $\begin{array}{l}\text { Land development } \\
\text { pressure }\end{array}$ & $\begin{array}{l}\text { Housing units incensement } \\
\text { between } 2000 \text { and } 2005\end{array}$ & $\begin{array}{l}\text { Census } 2000 \\
\text { and American } \\
\text { Community } \\
\text { Survey } 2005^{\star *}\end{array}$ \\
\hline $\begin{array}{l}\text { Impact of } \\
\text { population growth }\end{array}$ & $\begin{array}{l}\text { Population change from 1990-2000 } \\
\text { within a jurisdiction }\end{array}$ & Census 2000 \\
\hline $\begin{array}{l}\text { Population } \\
2000\end{array}$ & Population in each jurisdiction & Census 2000 \\
\hline Wealth & $\begin{array}{l}\text { Median family income } \\
\text { (in } 2000 \text { inflation-adjusted dollars) }\end{array}$ & Census 2000 \\
\hline Education & $\begin{array}{l}\text { Percentage of persons whose age is } \\
\text { above } 25 \text { with bachelor's degree or } \\
\text { higher, in } 2000\end{array}$ & Census 2000 \\
\hline Land area & Total land areas (square miles) & $\begin{array}{l}\text { California spatial } \\
\text { information library }\end{array}$ \\
\hline $\begin{array}{l}\text { Jurisdiction } \\
\text { type }\end{array}$ & $\begin{array}{l}\text { County, beach community, inland } \\
\text { community (categorical variable) }\end{array}$ & CAPBOL 2007 \\
\hline
\end{tabular}

* The missing items were found through further reviewing local land use general plans, or information requesting to local jurisdictions, or imputation calculations.

** Housing units of 2005's data are unavailable in some jurisdictions. This study uses the population change rates to impute the missing units.

\subsection{Planning capacity}

Since local planning departments are the lead agencies to conduct local land use plan's environmental assessments, planning capacity directly influences EIR quality through growth management, environmental assessment, and hazards management. Rational planning theory supports using adequate qualified planners, regularly updating plans, and improving technical skills in local comprehensive land use planning. In addition, the theory of pragmatism suggests that knowledge-based experience helps develop an efficient, adaptable, relevant, realistic and pragmatic planning process (Lawrence, 2000). Thus there is an increasing voice in environmental planning for streamlining, harmonization, procedural integration, and scoping. Therefore, planning capacity can be measured by the number of planners, plan updating ability, financial capacity, collaborative efforts, assessment scope, streamlining ability, information sharing, and professional and technical levels.

\subsubsection{Number of planners}

Planners are associated with increased levels of personnel, financial resources, technical expertise, and commitment to build a high quality planning outcome (Brody, 2003a,b; Brody et al., 2004; Burby and May, 1998). Planning staffs serve as internal consultants by developing specialized skills needed by the planners (Kartez and Lindell, 1987; Lindell and Meier, 1994). The planners may directly influence local land use planning and its EIR's quality.

\subsubsection{Plan updating ability}

Plan updating ability can measure local jurisdictions' capacity for land use planning and environmental management. Local land use planning is a dynamic process which is based on a snapshot of jurisdictional values, politics, economics, and environmental conditions at a particular planning range (Brody, 2003b,c). An on-time, regular plan update procedure helps an EIR to stay current with new information, conditions, regulations, and techniques.

\subsubsection{Collaborative efforts}

Brody (2003c) found that inter-organizational relations significantly influence local adoption of planning measures. California requires local jurisdictions to coordinate the preparation of local land use plans with local intergovernmental agencies. Collaboration with other jurisdictions or agencies is critical for a local jurisdiction to develop a high quality EIR because many issues are cross-boundary. Local jurisdictions working together with other organizations can achieve broader goals, help solve current problems, and reduce the potential for disputes.

\subsubsection{Assessment scope}

Assessment scope measures what kinds of proposals have been considered in the environmental assessment process (Treweek, et al., 1998). In order to identify particular environmental issues and assess their potential impacts, it is necessary to set the context within which the assessment is to take place by identifying critical environmental issues and problems to be addressed, the type of environmental assessment to be undertaken, and the intended objectives of the assessment for local land use planning. Environmental assessment scoping highlights environmental requirements and criteria at the outset and presents an opportunity to identify the relevant stakeholders, identify the availability and quality of data, and determine a set of appropriate tools and techniques to address the issues at hand.

\subsubsection{Streamlining ability}

The streamlining process refers to the process for compliance with environmental laws applicable to a given proposal. It can minimize duplication and overlaps in environmental assessment and planning (Jain, 2002). Streamlining achieves efficient identification, effective evaluation and timely resolution of environmental 
and regulatory issues. Streamlining can help establish "one decision-making process" for land use environmental assessment decision-making. Streamlining the environmental review process and minimizing the regulatory burden is important because it means efficient and thorough consideration of proposals, and reduced costs for environmental assessment procedures.

\subsubsection{Information sharing}

A critical element in EIRs is managing the environmental information and sharing with government officials, the judiciary, legal practitioners, academia, and the public at large. Web-based information is an effective way to achieve the purposes of public access (Zellmer and Eastman, 1997). This indictor is measured by jurisdictions that regularly post environmental assessment documents including a notice of preparation, EIRs, negative declaration, and other information.

\subsubsection{Professional technical skills}

Technical skill has been identified as an important factor in preparing high quality plans (Berke and French, 1994). Specifically, the Geographical Information System (GIS) has been widely recognized as an important planning tool. GIS can help planners understand precisely where critical environmental resources are and the degree to which they are in need of protection and help them make proactive choices about the strategic management of the existing environment.

\subsection{Public participation}

The theory of collaboration and communication supports strong public participation capacity in local land use planning through public participation (Sinclair and Diduck, 2001), collaborative learning (Armitage, 2005; Day, 1997; Diduck and Mitchell, 2003), and adaptive management (Noble, 2000). Public participation in environmental assessment creates an open and accessible decision-making process for environmental issues and achieves a goal that is economically feasible, environmentally sound, and human health conscious. Public participation capacity variables will systematically determine whether public participation has contributed to enhance the quality of EIRs. Three factors selected to analyze public participation capacity include participation formats, public notice channels, and public participation incentives.

\subsubsection{Participation formats}

Public hearings and workshops are the most frequently used public participation methods (Brody et al., 2003). According to the Brown Act enacted in 1953, local jurisdictions in California must provide advance public notice of hearings and meetings, and they must be open to the public if no exceptions apply. CEQA also requires public hearings prior to most planning actions and draft EIRs. Advance notice of the place and time of the public hearing must be published in the newspaper and also mailed directly to involved citizens. The public can be involved in adopting or amending a plan in a variety of ways.

\subsubsection{Public notice channels}

Multiple public participation channels can help overcome linguistic, institutional, cultural, economic, and historic barriers to achieve effective communication. Effective public participation should provide notice channels to enable the public discuss the information, opinions and concerns which may be relevant to land use decisions. Multiple public notice channels can thereby increase the accountability and transparency of land use decision-making and contribute to public awareness of environmental issues (Vanderhaegen and Muro, 2005). The most frequently used public notice channels may include the internet, newspapers, radios, television, mail, notices, and community newsletters.

\subsubsection{Public participation incentives}

Active public participation should develop incentive strategies that allow for early and meaningful public participation in environmental assessment by neighborhood organizations, development representatives, business organizations and all other stakeholders (Brody et al., 2003). Because many neighborhoods generally lack leadership and resources for public participation, they do not have the same level of influence on the final plan decision-making. Thus, public participation incentives provide a chance for local land use decision-makers to seriously consider public concerns and actually address those concerns. With public participation incentives, people have an opportunity to come together and work to solve possible environmental conflicts in a collaborative spirit that forms community solidarity.

\subsection{Environmental sensitivity}

Environmental sensitivity may be able to significantly influence local environmental management. A jurisdiction with greater environmental sensitivity may have more environmental protection duties and possible environmental conflicts in its land use planning. Increased environmental sensitivity can be a measure of the reduced feasibility for land use patterns and is expected to dampen local elected officials' commitment to planning (Norton, 2005). In Norton's (2005) conceptual model, the indictors of environmentally sensitive lands, development pressure, and population changes were used to explain local elected officials' commitment and planning outcomes.

\subsubsection{Critical environmental lands}

Critical environmental lands play a role in open space and preserving the natural environment (Norton, 2005). In this study, the critical environmental lands are measured by the percentage of public and conservation lands since approximately half of American lands are federally owned. Meanwhile, due to the constraints of public and conservation land ownership and geographic unsuitability, many new land development plans are concentrated in certain areas, especially in the coastal valleys, agricultural lands, and ecologically sensitive foothills which are all critical environmental components. Public and conservation lands are playing important roles with respect to local natural resources, open space, ecosystems, biodiversity, recreation and education. Public and conservation lands are usually subjected to a higher standard of environmental protection. More financial resources, personnel, management capacities, and collaborative efforts with multiple organizations are expected for public and conservation lands management.

\subsubsection{Land development pressure}

Land development pressure may alert local officials to resource threats and lead to improve planning outcomes (Norton, 2005). Land development pressure is measured by newly increased housing units or permits. The more new housing units or permits increase, the more land development pressure can be expected. Land development pressure is associated with higher levels of disturbance to environment quality, resulting in a greater perceived need to protect the environment.

\subsubsection{Impact of population growth}

Rapid population growth has a substantial effect on environmental quality (Norton, 2005). Population growth may consume more natural resources and built-environment resources; at the same time, it also creates more waste and pollution. Potential land use conflicts may increase with population growth, resulting in a greater demand for environmental management.

\subsection{Contextual variables}

The contextual variables can measure the influence of background information on EIR quality. Based on the literature, this 
study chooses population, wealth, and education as contextual variables. In this study, five major factors have been used to analyze the contextual influence on EIR quality. Many previous planning models (Brody, 2003c; Brody, et al., 2003, Godschalk et al., 2003; Scott and Willits, 1994) adopt similar contextual variables to detect the influences from the background information.

\subsubsection{Population}

Population has been identified as an important contextual factor in local land use planning (Brody, 2003c). Local jurisdictions with larger populations may have more expertise, resources and financial support for a local land use plan's environmental assessment, but may also face more environmental pressure and problems. Thus, more population may lead to both higher consideration of and stronger capacity for environmental assessment.

\subsubsection{Wealth}

Wealthy people often have more time and interest in environmental issues (Scott and Willits, 1994; Van Liere and Dunlap, 1981). Wealthier populations tend to be well-educated; thus they may be more concerned about environmental protection and pursue a higher environmental quality.

\subsubsection{Education}

Education also has been identified as an important factor contributing to environmental issues (Brody et al., 2004; Guagano and Markee, 1995; Howell and Laska, 1992; Raudsepp, 2001). Communities with a more highly educated population can influence the planning process and encourage higher levels of environmental protection. A community with a high education level tends to have an enhanced perception of the need for environmental protection and more enthusiasm for participating in environmental management activities.

\subsubsection{Land area}

Land area may influence local environmental assessment. Larger land areas may need more personnel resources and have more concerns.

\subsubsection{Jurisdiction type}

Jurisdiction type may also influence local environmental assessment quality. Norton's (2005) findings suggest that various jurisdiction types may lead to various planning outcomes. This study will compare the EIR quality across coastal communities, municipalities, and counties.

\section{Methods}

\subsection{Sample selection}

California is an ideal study area because there is a state mandate for local jurisdictions to conduct environmental assessment for their land use plans. California has the most restrictive environmental assessment requirements among the 50 states to protect environmental quality in the long-term. In addition, California, a state with high population density, intense land use demands, and a rapid growing economy, is faced with pressure from population growth, environmental management, and local development in the state. California's economy is the largest of any state in the United States. California ranks first in plant and animal diversity and number of rare species (California Office of Planning and Research, 2003). As California's population grows, rapid urbanization and extensive land demands are expected to cause numerous conflicts and bring heavy pressure on natural resources and environmental quality.

The population of this study comprises the EIRs (or draft EIRs) of local land use general plans from all jurisdictions in California.
The dataset was constructed by first searching each jurisdiction's web site and the California Land Use Planning Information Network web site to find the information on land use general plan's EIRs. This study found that 65 jurisdictions recently conducted EIRs for their land use general plans and post related EIR information on their websites. After three round requests by phone calls, emails, or mails to get the EIRs that are unavailable on line, this study eventually collected 40 EIRs or draft EIRs by January 20, 2007. Another 15 jurisdictions were not included because they did not make their EIRs available on a web site, made no response to repeated requests, or were still waiting for final approval. The EIRs in this study covered $7.5 \%$ of the 534 California local jurisdictions.

For independent variables, this study uses the California Planners' annual survey data from the California Planners' Book of List (CAPBOL). The missing items in this survey are updated by a webpage survey or emails to local jurisdictions. 2000 census data is used to measure some contextual characteristics. Finally, GIS data came from the California Spatial Information Library.

\subsection{Scoring indicator quality}

The preceding conceptualization of EIR quality leads to the EIR evaluation coding protocol. Each component is evaluated by scanning all elements to assess whether they have addressed the 63 indicators of the five plan components: 1) factual basis, 2) goals and objectives, 3) tools, approaches, and methodologies, 4) coordination and communication, 5) implementation, monitoring, mitigation, and alternatives. Within these five components, each indicator is scored on a $0-2$ scale. A score of " 0 " means the indicator is not mentioned in the plan, a score of " 1 " means that an indicator is considered but not thoroughly, and a score of " 2 " means the indicator is fully considered. The first author of this paper evaluated and scored all of the EIRs quality by using the evaluation protocol. Total and component EIR quality are calculated by the equations as follows:

$$
\mathrm{PC}_{j}=\frac{10}{2 m_{j}} \sum_{i=1}^{m_{j}} I_{i} \quad \text { and } \quad \mathrm{TPQ}=\sum_{j=1}^{5} \mathrm{PC}_{j},
$$

where $\mathrm{PC}_{j}$ represents the quality of the $j$ th plan component (ranging $0-10) ; m_{j}$ represents the number of indicators within the $j$ th plan component; $I_{i}$ represents the $i$ th indicator's score (ranging 02 ); and TPQ is the total scores of a whole plan (ranging 0-50).

\subsection{Data analysis}

The research includes two stages of data analysis: First, this study uses descriptive statistics to assess the quality of the 40 sampled EIRs. Second, this study uses Pearson's Product-Moment correlation coefficients and multiple regression analysis to analyze the factors affecting the quality of EIRs. The ordinary least squares technique was introduced into this study to measure what kinds of factors influence local land use plan's EIR quality.

This study conducted the related reliability statistical tests to ensure that the ordinary least squares would yield best, linear, and unbiased estimates. There is no violation of regression assumptions regarding model specification, multicollinearity, heteroskedasticity, autocorrelation, influential data or outliers, or inter-item correlation and scale reliability.

\section{Results}

\subsection{Descriptive statistics}

The descriptive statistics for each component and total EIR quality are listed in Table 3. 
Table 3. Descriptive statistics for total quality and five components performance

\begin{tabular}{|c|c|c|c|c|c|}
\hline EIR components & $N$ & Min. & Max. & Mean & St. Dev. \\
\hline I. Factual basis & 40 & 3.86 & 10.00 & 6.56 & 1.38 \\
\hline II. Goals and objectives & 40 & 4.55 & 10.00 & 6.59 & 1.44 \\
\hline $\begin{array}{l}\text { III. Tools, approaches, and } \\
\text { methodologies }\end{array}$ & 40 & 2.06 & 9.41 & 5.02 & 1.67 \\
\hline $\begin{array}{l}\text { IV. Coordination and } \\
\text { communication }\end{array}$ & 40 & 2.00 & 10.00 & 4.77 & 1.96 \\
\hline $\begin{array}{l}\text { V. Implementation, monitoring, } \\
\text { mitigation, and alternatives }\end{array}$ & 40 & 4.00 & 10.00 & 6.78 & 1.71 \\
\hline Total & 40 & 20.10 & 46.01 & 29.73 & 6.64 \\
\hline
\end{tabular}

The mean score for the EIR quality is 29.73 on a scale of $0-50$. This means for the total quality score indicates that the local jurisdictions' work is slightly above average quality for EIRs, but there is still a large room to improve the EIR quality. Additionally, large variations of the EIR quality are found across jurisdictions. Three counties (Madera, Ventura, and Placer County) receive very high quality performance with scores above 40 , and the highest score is presented by Placer County at 46.01 . Thirteen jurisdictions receive a relatively good performance with scores above 30; however, the rest of twenty-four jurisdictions' EIR quality is relatively weak, with scores less than 30 . The lowest score is only 20.10 , received by City of Rio Dell.

For the five components' performance, the implementation, monitoring, mitigation, and alternatives component has the highest score (6.78) of the five plan components, indicating stronger efforts for identifying critical environmental impacts and implementing the reports. Local jurisdictions are also willing to monitor, mitigate, and provide alternatives. Goals and objectives receive the second highest score (6.59) of these five plan components, meaning that jurisdictions have set relatively clear goals to protect local environmental quality. Factual basis received a score of 6.56, demonstrating a relatively good knowledge regarding the existing local environmental conditions. Tools, approaches, and methodologies receive a score of 5.02 indicating relatively weak quality, indicating local jurisdictions still have a long way to go to improve their current assessment tools, approaches, and methodologies. Coordination and communication only receive 4.77 , demonstrating that local jurisdictions did not make a very well coordinated effort at communication with other agencies, stakeholders, and citizens regarding the local land use plan's environmental impact assessment.
Although in general, a majority of the indicators received relatively high coverage in these EIRs, some of them are still weak (particularly the region-wide, global-wide, long-term, cumulative, and strategically critical environmental elements). In the factual basis component, only 9 (77.5\%) EIRs discussed the general plan's sphere of influence, and most of them failed to identify areas outside their planning boundaries or provide a regional context. Although local level indicators generally received high scores, the large-scale indicators are weakly identified by local land use plans. For example, greenhouse gas emission and climate change received the lowest coverage $(10 \%)$ in the factual basis plan component. Ozone layer depletion also receives very low coverage $(17.5 \%)$. In the goals and objectives component, although local jurisdictions have visions to improve local environmental quality, environmental justice and equity were the least understood (10\%) of these goals and objectives. In the environmental assessment tools component, the traditional environmental assessment tools and approaches received high coverage. Only $15 \%$ of the local jurisdictions adopted cost-benefit analysis to evaluate the relative merits of a strategic action and incorporate environmental costs into their environmental assessment and review. More importantly, few jurisdictions have adequate incentives or the capacity to incorporate ecological footprint analysis (20\%), life cycle analysis $(15 \%)$, or risk and vulnerability assessment $(20 \%)$ as environmental assessment tools. For the coordination and communication component, few $(17.5 \%)$ jurisdictions specify trans-boundary environmental issues and identify effective information accessibility, notification and dissemination. With respect to the implementation, monitoring, mitigation, and alternative component, relatively few local plans commit financial resources $(17.5 \%)$, or identify reliable financial support for implementation $(20 \%)$.

In order to detect why the EIR quality varies in scope and contents, the following sections discuss the factors influencing EIR quality and variations.

\subsection{Correlation results}

The Pearson's Product-Moment correlation coefficients indicate the degree of association among variables. The correlation matrix in Table 4 shows independent variables which are significantly correlated $(p<.05)$ with the dependent variable-EIR quality. According to the correlation coefficients, this study ranks the correlation relationships between each variable and the EIR qual-

Table 4. Correlation matrix

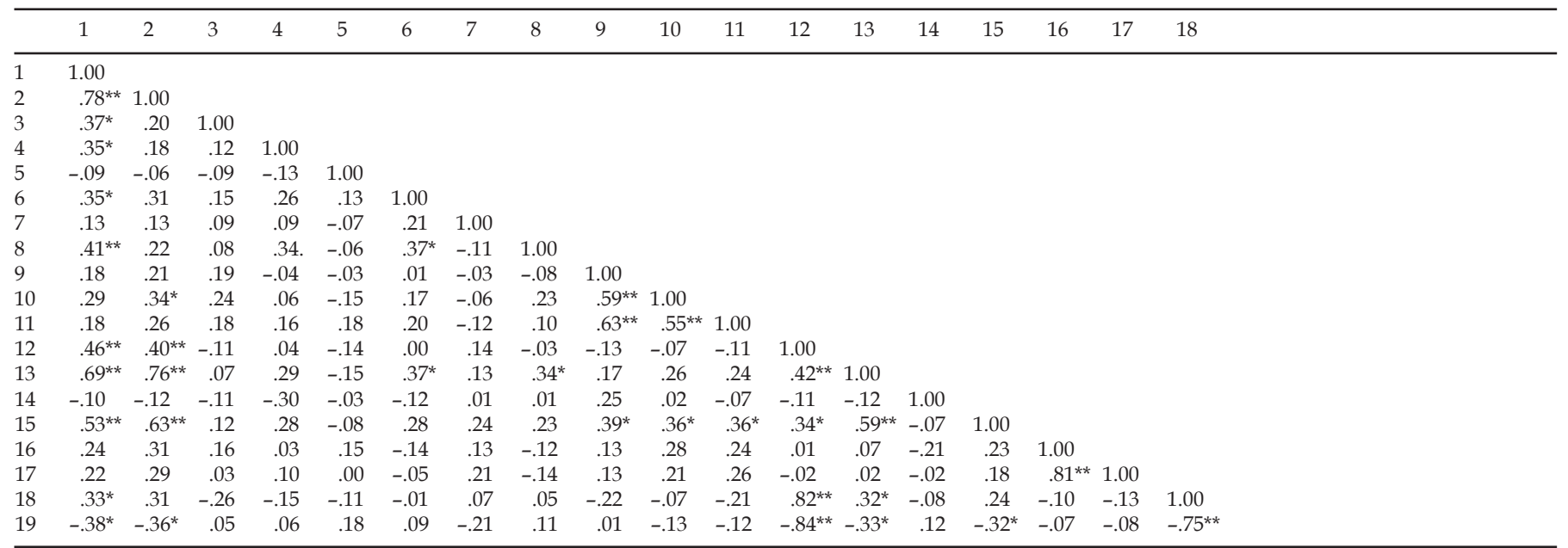

(**Significant at .01 level; * ${ }^{*}$ significant at .05 level $)$.

(Code Statement for the variables: 1: EIR quality; 2: Number of planners; 3: Plan dating ability; 4: Collaborative efforts; 5: Assessment scope; 6: Streamlining ability; 7: Information sharing ability; 8: Professional technical skill; 9: Public participation format; 10: Public notice channel; 11: Public participation incentives; 12: Critical environmental lands; 13: Land development pressure; 14: Impact of population growth; 15: Population; 16: Income; 17: Education; 18: Area; 19: Jurisdiction type). 
ity as follows: number of planners $\left(r=.78^{* *}\right)>$ land development pressure $\left(r=.69^{* *}\right)>$ population $\left(r=.53^{* *}\right)>$ critical environmental lands $(r=.46 .)>$. professional technical skills $>\left(r=.41^{* *}\right)>\mathrm{ju}-$ risdiction type $(r=.38$. $)>$ plan updating ability $(r=.37$. $)>$ collaborative efforts $(r=.35$.) or streamlining ability $(r=.35$. $)>$ land area $(r=.33$. $)>$ public notice channel $(r=.29)>$ income $(r=.24)>$ education $(r=.22)>$ public participation incentives $(r=.18)$ or public participation format $(r=.18)>$ information sharing $(r=.13)>$ impact of population growth $(r=-.10)>$ assessment scope $(r=-.09)$. This rank indicates that some variables are more correlated with EIR quality than others.

Five planning capacity variables (including number of planners, plan updating ability, collaborative efforts, streamlining ability, and professional technical skills) have significant correlations with EIR quality. Land development pressure, critical environmental lands, population, jurisdiction types and land areas also show significant correlations with EIR quality. No public participation variables have a statistically significant correlation with EIR quality, although numerous previous studies have highlighted the role of public participation in the planning process. The correlation matrix also highlighted some inter-variable correlation relationships that can cause interactive impacts on EIR quality. To further detect the independent variables' influence on plan quality, the following section extends the correlation analysis to regression analysis.

\subsection{Regression results for independent variables}

The correlation results can quantify the degree to which two variables are statistically related, however, correlation is not enough to examine the factors influencing EIR quality. Correlation does not find a best-.t line as the regression model did since it doesn't detect the cause and effect. In addition, correlation is almost always used to measure both variables; thus, the regression models with $F$-tests are used to determine which variables in each set of variables are statistically significant at the .05 and .01 significant levels. The regression results in Table 5 further highlight the relationship of the four sets of independent variables with the EIR quality.

\subsubsection{Planning capacity results}

The results of the regression analysis for planning capacity variables suggest that the number of planners and plan update ability make a statistically significant contribution to EIR quality.

The number of planners has a statistically $(p=.000)$ positive impact on local land use plan's EIR quality. High numbers of planners can bring more human resources, expertise and personnel to the local land use plan's environmental assessment process; therefore, more planners may lead to higher quality EIRs. More qualified planners lead to higher quality environmental plans, particularly with respect to technically-driven aspects such as environmental impact analysis.

The plan update ability has a statistically significant impact on EIR quality $(p=.036)$. This result demonstrates that more recent updated plans have a statistically higher EIR quality than do outof-date plans. An on-time, regular plan updating helps EIRs keep abreast of existing new information, conditions, regulations, and techniques and leads to higher EIR quality. Regular plan updating has been identified as the most powerful factor influencing EIR quality.

The effect of professional technical skill is close $(p=.073)$ to the significance level of .05; it would be expected that greater professional technical skill would increase the quality of plans while controlling for other planning capacity variables. Further research may be needed to clarify this relationship.

Collaborative efforts were measured by the jurisdictions participating in regional collaborative planning efforts. Although many theories highlighted collaborative efforts in planning quality (Brody, 2003c; Brody et al., 2003, 2004), this study did not find statistical significance in collaborative efforts on EIR quality. Streamlining ability and information sharing did not show significance with EIR quality. Surprisingly, assessment scope has a negative impact on EIR quality; the reason may be relatively fewer variations in this variable itself.

\subsubsection{Public participation capacity results}

In regard to public participation capacity variables, no variable made a statistically significant contribution to EIR quality. The result of this model is not significant $(p=.356)$, indicating that public participation capacity does not result in high quality EIRs. While public participation variables do not have a statistically significant impact on EIR quality, they are surely important in the EIR process for other reasons (qualitative data collection, political acceptance, etc.).

Table 5. Regression results

\begin{tabular}{|c|c|c|c|c|c|}
\hline Category & $\begin{array}{l}\text { Independent } \\
\text { variables }\end{array}$ & Coefficient & $\begin{array}{l}\text { Standardized } \\
\text { coefficient }\end{array}$ & $t$-Value & $p$-Value \\
\hline $\begin{array}{l}\text { Planning } \\
\text { capacity }\end{array}$ & $\begin{array}{l}\text { Number of planners } \\
\text { Plan updating ability } \\
\text { Collaborative efforts } \\
\text { Assessment scope } \\
\text { Streamlining ability } \\
\text { Information sharing } \\
\text { Professional technical } \\
\text { skill } \\
N=40 \\
\text { F-ratio }(7,32)=12.532 \\
\text { Significance }=.000 \\
\text { Adjusted } R \text { square }=.674\end{array}$ & $\begin{array}{r}.544 \\
.224 \\
.486 \\
-.069 \\
.003 \\
.269 \\
.786\end{array}$ & $\begin{array}{r}.669 \\
.206 \\
.136 \\
-.002 \\
.001 \\
.033 \\
.197\end{array}$ & $\begin{array}{r}6.771 \\
2.186 \\
1.354 \\
-.024 \\
.005 \\
.338 \\
1.856\end{array}$ & $\begin{array}{l}.000^{* *} \\
.036^{*} \\
.185 \\
.981 \\
.996 \\
.738 \\
.073\end{array}$ \\
\hline $\begin{array}{l}\text { Public } \\
\text { participation } \\
\text { capacity }\end{array}$ & $\begin{array}{l}\text { Public participation } \\
\text { format } \\
\text { Public notice channel } \\
\text { Public participation } \\
\text { incentives } \\
N=40 \\
F \text {-ratio }(3,36)=1.15 \\
\text { Significance }=.356 \\
\text { Adjusted } R \text { square }=.009\end{array}$ & $\begin{array}{r}.005 \\
\\
1.516 \\
.124 \\
\\
\\
\\
\\
\\
\\
\end{array}$ & $\begin{array}{l}.001 \\
.271 \\
.034\end{array}$ & $\begin{array}{r}.003 \\
1.312 \\
.161\end{array}$ & $\begin{array}{l}.998 \\
\\
.198 \\
.873\end{array}$ \\
\hline $\begin{array}{l}\text { Environmental } \\
\text { sensitivity }\end{array}$ & $\begin{array}{l}\text { Critical environmental } \\
\text { lands } \\
\text { Land development } \\
\text { pressure } \\
\text { Impact of population } \\
\text { growth } \\
N=40 \\
F \text {-ratio }(3,36)=12.541 \\
\text { Significance }=.000 \\
\text { Adjusted } R \text { square }=.470\end{array}$ & $\begin{array}{l}.062 \\
.001 \\
-.329\end{array}$ & $\begin{array}{r}.207 \\
.602 \\
-.005\end{array}$ & $\begin{array}{l}1.603 \\
4.660 \\
-.040\end{array}$ & $\begin{array}{l}.118 \\
.000^{* *} \\
.968\end{array}$ \\
\hline $\begin{array}{r}\text { Contextual } \\
\text { variables }\end{array}$ & $\begin{array}{l}\text { Population } 2000 \\
\text { Wealth } \\
\text { Education } \\
\text { Land area } \\
\text { Jurisdiction type } \\
N=40 \\
F \text {-ratio }(5,34)=3.813 \\
\text { Significance }=.008 \\
\text { Adjusted } R \text { square }=.265\end{array}$ & $\begin{array}{ll} & 1.130 \mathrm{E}-05 \\
& 4.226 \mathrm{E}-05 \\
& .046 \\
& .002 \\
& -.774 \\
& \\
& \\
& \\
& \end{array}$ & \begin{tabular}{r|}
.421 \\
.085 \\
.087 \\
.179 \\
-.097
\end{tabular} & $\begin{array}{r}2.825 \\
.359 \\
.363 \\
.833 \\
-.448\end{array}$ & $\begin{array}{l}.008^{* *} \\
.722 \\
.719 \\
.411 \\
.657\end{array}$ \\
\hline $\begin{array}{l}\text { Fully specified } \\
\text { model }\end{array}$ & $\begin{array}{l}\text { Number of planners } \\
\text { Plan updating date } \\
\text { Land development } \\
\text { pressure } \\
\text { Population } \\
N=40 \\
F \text {-ratio }(4,35)=19.783 \\
\text { Significance }=.000 \\
\text { Adjusted } R \text { square }=.658\end{array}$ & $\begin{array}{l}.425 \\
.270 \\
.000 \\
\\
3.643 \mathrm{E}-07\end{array}$ & $\begin{array}{l}.522 \\
.248 \\
.268\end{array}$ & $\begin{array}{l}3.337 \\
2.580 \\
1.805\end{array}$ & $\begin{array}{l}.002^{\star *} \\
.014^{*} \\
.080\end{array}$ \\
\hline
\end{tabular}

(** Significant at .01 level; ${ }^{*}$ significant at .05 level). 
Public participation is a difficult issue since it is technically not possible to expect participation from political, economical, technical and wide-ranging sources. Public participation processes are criticized as ineffective by participants, costly and time consuming by proponents, and inefficient by governments. This regression result shows that effectively translating public participation efforts into practical environmental assessment is thereby a critical issue for both planning agencies and environmental agencies. This result indicates that more numbers of participation formats, public notice channels, or public participation incentives do not produce higher quality EIRs.

Although many articles have highlighted public participation's influence on land use planning outcomes (Godschalk et al., 2003), no variable was statistically significant in this study. It is difficult to reflect public participation capacity in local environmental assessment products. The jurisdictions with stronger public participation may not have a measurably better EIR; however, public participation is a positive influence on the EIR process as a whole.

\subsubsection{Environmental sensitivity results}

Increased development pressure shows statistical $(p=.000)$ significance with EIR quality. The jurisdictions with increased housing development pressure devote more effort and show heightened commitment to EIR quality in their land use planning. Higher land development pressure may push local jurisdictions to make more strict consideration on existing critical natural resources and important environmental areas.

Although critical environmental lands did not present significantly with EIR quality, it still showed a positive $(p=.118)$ impact on EIR quality. The impact of population growth did not significantly influence EIR quality.

\subsubsection{Contextual characteristics results}

Contextual conditions are variables that might directly or indirectly influence local land use plan's EIR quality. Among the contextual characteristics variables, only population is statistically significant $(p=.008)$. Local jurisdictions with larger populations may have relatively more expertise and resources to conduct effective environmental assessment and to deal with the possible environmental conflicts in the development process. Thus, population is an important contextual factor in EIR quality. The jurisdictions with more population often have more environmental pressure and conflicts that result in a need for stronger EIR quality since jurisdictions with larger populations tend to have higher levels of disturbance to the environment, resulting in a greater perceived need to protect or improve existing EIR quality.

Income, education, and land areas all suggest positive relationships with EIR quality even if they are not statistically significant. The jurisdiction types (coastal community, county, and municipality) did not show statistical evidence for EIR quality.

\subsubsection{Fully specified regression model}

Based on the results of regression analysis examining the four categories of variables, this study constructs a fully specified model to further examine the influencing factors on plan quality. The fully specified regression model finally groups these variables which have shown significance in four categories. The fully specified model includes the number of planners, plan update date, land development pressure, and population of each jurisdiction in the sample. Since the correlation matrix indicates that these four variables are significantly correlated with each other, the fully specified regression model can further clarify the contribution of each variable to final EIR quality. In this final model, the number of planners and population remained the most significant variables with a positive impact on plan quality $(p=.002)$. The plan update date continues to have a significant impact on plan quality $(p=.014)$. Although land development pressure did not show significance at the .05 level $(p=.080)$, its standardized coefficient of .268 is even higher than the plan update date at .248. If we extend our consideration for the significance level to .10 , land development pressure still indicates positive impacts on EIR quality.

This fully specified regional model further highlights the factors contributing to EIR quality. This result suggests that the number of planners, plan update date, and land use pressure variables are the most powerful predictors of local EIR quality. To further test the model specification, or to see how robust the coefficients of independent variables are to changes in the model, this study conducted a sensitivity analysis by detecting the extreme bounds of the variables in the final model. The result is consistent with the findings in the fully specified model.

In summary, findings reveal important insights into the influences on local land use plan's EIR quality. Additionally, these results are useful for informing local environmental assessment activities. Since this study only analyzed 40 EIRs, the validity of the statistical conclusion may be influenced by a relatively low level of statistical power in the multiple regression models. Thus, this study must be cautious when extending conclusions.

\section{Conclusions, discussions, and policy implications}

Regarding the first question ("How well do local jurisdictions in California develop high quality EIRs for local land use plans?"), the descriptive results indicate that the EIR quality varied in scope and contents. Although these EIRs had generally acceptable quality, they still have a long way to go to reach a high quality level. The descriptive results indicate that there are large variations in quality across local jurisdictions' EIRs. Although local jurisdictions' EIRs made a relatively high coverage for a majority of the indicators, they generally weakly addressed the region-wide, globalwide, long-term, cumulative, strategically critical environmental elements and related tools, policies, and mechanisms.

Regarding the second question ("Which factors influence the quality of local land use plan's EIRs?"), the explanatory results have highlighted the most important factors for local land use plan's EIR quality as: 1) number of planners, 2) plan updating ability, and 3) development pressure. First, the explanatory results suggest that higher numbers of planners can bring more human resources, expertise and personnel to the local land use plan's environmental assessment process. Therefore, more planners can lead to higher quality EIRs; however, jurisdictions with understaffed planning agencies are at a distinct disadvantage when it comes to developing high quality EIRs for their land use plans. Second, plan updating ability is also critical for EIRs quality from the explanatory results since an on-time, regular plan element update procedure helps EIRs keep abreast of existing new information, conditions, regulations, and techniques and leads to higher quality. Third, development pressure positively influences local land use plan's EIR quality since more housing permits may unavoidably exert significant effects on the existing environmental system. The jurisdictions with higher development pressure tend to have higher levels of disturbance to the environment, resulting in a greater perceived need to protect the local environment, and that can lead to higher quality EIRs. Finally, the interactive relationship of these variables may also have complex influences on EIR quality. These findings can lead to improving local land use plan's environmental assessment through training planners, integrating development pressure, and updating land use plans regularly.

Regarding the third question ("How can local planning process be improved to enhance EIRs' quality and effectiveness?"), this study makes the following policy recommendations.

The first policy implication is to educate planners and decision makers to know the strategic environmental impacts that are critical in local land use plan's environmental assessment. The descrip- 
tive results show that many EIRs still stay at only moderate quality and many long-term, cumulative, and large-scale environmental issues, tools, and mechanisms are weakly identified in current EIRs. This study also found that number of planners could significantly contribute to local land use plan's EIR quality. Local planning departments are the lead agencies to conduct local land use plan's environmental assessments; planners' abilities directly influence EIR quality through either daily permitting activities or long-term strategic plans. A qualified planner can take important responsibilities to protect local environmental quality; thus it is critical to educate planners and decision-makers to know the strategic environmental impacts (e.g. biodiversity, ecosystem, watershed, wetland, or even global warming) in local land use planning for more sustainable development. Planners should facilitate rational planning and decision-making, and manage the adverse impacts of proposed land use planning actions in particular.

The second policy implication is to make more adaptive management through integrating land use development pressure into local land use plan environmental assessments. The explanatory results have identified that land development pressure has significant effects on EIR quality. An important issue for environmental assessment thus becomes finding ways to motivate local jurisdictions to protect critical environmental resources before they are lost to development. Traditional project-by-project environmental assessment is inadequate for a long-range, holistic consideration. Local land use plan EIRs can emphasize a more long-term perspective. Local agencies improve the old management model that tends to consider daily activities such as zoning and subdivision review over long-term strategic planning. Integrating land development with environmental assessment is not only an effective method to gather information and assist the decision-making process but also a practical tool to analyze environmental impacts and develop relevant, specific mitigation measures. Adaptive environmental management can help local planning agencies to improve the EIR quality by solving numerous problems and conflicts from land development and integrating environmental assessments as early in local land use planning process as possible.

The third policy implication is to keep a regular environmental updating procedure. A key finding from the regression models is that regular plan updates are critical for environmental assessment quality. EIRs should reflect changes and continually monitor the relevance of land use plan elements to ensure that they remain current with evolving conditions. If monitoring reveals an EIR inadequacy, local EIRs should be updated or revised. A regular environmental update can improve EIR quality by generating more specific goals and policies.

The fourth policy implication is to reexamine the role and the effectiveness of public participation in the local planning process, and then find an appropriate way to enhance the actual effectiveness of participation on EIR final quality. The explanatory results indicated that none of public participation variables are significantly contributing to EIR quality. The result identified a gap between public participation efforts and final EIR quality. Although past studies (Healey, 1992) have shown the importance of public participation in local land use planning, this study did not find the statistical evidence to support the hypothesis that stronger public participation can result in higher EIR quality. Many past studies (Lawrence, 2000) have highlighted that public participation may help cope with uncertainty and conflict and facilitate effective joint participation through identifying stakeholders' interests, building more transparent decision- making processes, more creative dispute solving and greater public involvement; however, it may also result in a longer duration for decision-making and a costly environmental assessment process. In addition, different stakeholders have various levels of power and resources to affect the decisionmaking process, resulting in unequal impacts on the decisions in EIRs. Thus, it is difficult to ensure absolute equity in the distribu- tion of benefits and costs resulting from the environmental assessment. More importantly, public participants generally pay close attention to their own interests because of "not-in-my-backyard" and "locally unwanted-land-use attitudes" (Fischer, 2003). Public interest tends to focus on more tangible development proposals in local neighborhoods rather than abstract, comprehensive and long-term development proposals (Altshuler, 1965). The general public tends to consider local issues which are directly related to them rather than region-wide or global-wide issues. Both the planning agencies and environmental specialists need to concentrate on how to effectively reflect the opinions of public participants in the final EIRs.

\section{Limitations and future studies}

This study provides a greater understanding of local land use plan EIR's quality and the factors influencing it, it is also a primer for research to investigate the topic in California. This study has several limitations. A relatively small sample size may lack enough statistical power to extend the conclusions to other jurisdictions. Furthermore, a major limitation of this study is how to count the influence of consulting efforts in EIR quality since all of the EIRs were actually completed by various environmental consulting companies. In addition there is the difficulty of expressing a dynamic process of local environmental assessment that is actually reflected in final EIR quality. The impact of possible influential data points may also disturb the conclusions of this study. Finally, while this study's results could be extended to other places, geographical variations, socioeconomic characteristics, and policy frameworks can be external validity threats.

Future study will expand the sample size and introduce more variables to further examine the quality of local land use plan EIRs and the factors influencing EIR quality.

\section{Acknowledgments}

The authors gratefully appreciate the anonymous reviewers' comments that greatly improved this paper. We also thank Dr. Hao Mei from Duke University for his kind help in statistical methods.

\section{References}

Altshuler A. The goals of comprehensive planning. J Am Inst Plann 1965; 31:186-95.

Armitage DR. Collaborative environmental assessment in the northwest territories, Canada. Environ Impact Asses Rev 2005; 25:239-58.

Berke PR, French SP. The influence of state planning mandates on local-plan quality. J Plann Educ Res 1994; 13:237-50.

Bonnell S, Storey K. Addressing cumulative effects through strategic environmental assessment: a case study of small hydro development in Newfoundal, Canada. J Environ Assess Policy Manag 2000; 2:477-99.

Brody SD. Examining the role of resource-based industries in ecosystem approaches to management: an evaluation of comprehensive plans in Florida. Soc Nat Resour 2003a; 16:625-41.

Brody SD. Are we learning to make better plans? A longitudinal analysis of plan quality associated with natural hazards. J Plann Educ Res 2003b; 23:191-201.

Brody SD. Measuring the effects of stakeholder participation on the quality of local plans based on the principles of collaborative ecosystem management. J Plann Educ Res 2003c; 22:407-19.

Brody SD, Godschalk DR, Burby RJ. Mandating citizen participation in plan making - six strategic planning choices. J Am Plan Assoc $2003 ; 69: 245-64$.

Brody SD, Highfield W, Carrasco V. Measuring the collaborative planning capabilities of local jurisdictions to manage ecological systems in southern Florida. Landsc Urban Plan 2004; 69:33-50. 
Brown AL, Therivel R. Principles to guide the development of strategic environmental assessment methodology. Impact Assess Proj Apprais 2000; 18(3):183-9.

Burby RJ. Have state comprehensive planning mandates reduced insured losses from natural disasters? Nat Hazards Rev 2005; 6(2):67-81.

Burby RJ, May P. Intergovernmental environmental planning: addressing the commitment conundrum. J Environ Plan Manag 1998; 41(1):95-110.

California Environmental Quality Act (CEQA). California Environmental Quality Act - public resources code reference sections 21003, 21060, 21061, 21083, 21100, 21104, 21151, and 21152. Sacramento, CA: California Resources Agency; 2006.

California Office of Planning and Research. Governor's environmental goals and policy report. Sacramento: Governor's Office of Planning and Research, California Office of Planning and Research; 2003. p. 20-40.

California Office of Planning and Research. California planning guide: an introduction to planning in California. Sacramento: Governor's Office of Planning and Research, California Office of Planning and Research; 2005. p. 1-40.

Canelas L, Almansa P, Merchan M, Cifuentes P. Quality of environmental impact statements in Portugal and Spain. Environ Impact Asses Rev 2004; 25(3):217-25.

Council on Environmental Quality (U.S.) (CEQ). Considering cumulative effects under the National Environmental Policy Act. Washington, DC: Council on Environmental Quality; 1997. p. 1-70.

Day D. Citizen participation in the planning process: an essentially contested concept? J Plan Lit 1997; 11(3):421-34.

Diduck A, Mitchell B. Learning, public involvement and environmental assessment: a Canadian case study. J Environ Assess Policy Manag 2003; 5(4):339-64.

Fischer TB. Strategic environmental assessment in transport and land use planning. London Sterling, VA: Earthscan Publications; 2002. p. 1-45.

Fischer TB. Strategic environmental assessment in post-modern times. Environ Impact Asses Rev 2003; 23:155-70.

Forester J. Bounded rationality and the politics of muddling through. Pub Adm Rev 1984; 44(1):23-31.

Furman E, Hilden M, editors. Transport planning: does the influence of strategic environmental assessment/integrated assessment reach decision-making. Final report of a workshop. The Finnish environment 534, land use. Helsinki: Edita; 2001. p. 1-82.

Godschalk DR, Brody SD, Burry R. Public participation in natural hazard mitigation policy formation: challenges for comprehensive planning. J Environ Plan Manag 2003; 46(5):733-54.

Gray IM, Edwards-Jones G. A review of the quality of environmental impact assessments in the Scottish forest sector. Forestry 1999; 72(1):1-10.

Guagano GA, Markee N. Regional differences in the sociodemographic determinants of environmental concern. Popul Environ 1995; 17(2):135-49.

Healey P. A planners day - knowledge and action in communicative practice. J Am Plan Assoc 1992; 58:9-20.

Hilden M, Furman E, Kaljonen M. Views on planning and expectations of SEA: the case of transport planning. Environ Impact Asses Rev 2004; 24(5):519-36.

Howell SE, Laska SB. The changing face of the environmental coalition: a research note. Environ Behav 1992; 24:134-44.

Jain RK. Environmental assessment. 2nd edition. New York: McGrawHill; 2002.

Jones C, Baker M, Carter J, Jay S, Short M, Wood C, editors. Strategic environmental assessment and land use planning: an international evaluation. London: Earthscan; 2005. p. 28. 300 pp.

Kartez JD, Lindell MK. Planning for uncertainty: the case of local disaster planning. J Am Plan Assoc 1987; 53(4):487-9.

Kuo NW, Hsiao TY, Yu YH. A Delphi-matrix approach to SEA and its application within the tourism sector in Taiwan. Environ Impact Asses Rev 2005; 25:259-80.

Lawrence DP. Planning theories and environmental impact assessment. Environ Impact Asses Rev 2000; 20:607-25.

Lawrence DP. Environmental impact assessment: practical solutions to recurrent problems. Hoboken: John Wiley \& Sons; 2003a. p. 1-20.
Lawrence DP. Environmental impact assessment: practical solutions to recurrent problems. Hoboken, NJ: John Wiley \& Sons; 2003b. p. 1-30.

Lindell MK, Meier MJ. Effectiveness of community planning for toxic chemical emergencies. J Am Plan Assoc 1994; 60:222-34.

Liou ML, Yeh SC, Yu YH. Reconstruction and systemization of the methodologies for strategic environmental assessment in Taiwan. Environ Impact Asses Rev 2006; 26(2): 170-84.

Munier N. Multicriteria environmental assessment. Ottawa: Kluwer Academic Publishers; 2004. p. 87-109.

Nelson AC, French SP. Plan quality and mitigating damage from natural disasters - a case study of the Northridge Earthquake with planning policy considerations. J Am Plan Assoc 2002; 68:194-207.

Noble BF. Strategic environmental assessment: what is it \& what makes it strategic? J Environ Assess Policy Manage 2000; 2(2):203-24.

Noble BF. Strategic environmental assessment quality assurance: evaluating and improving the consistency of judgments in assessment panels. Environ Impact Asses Rev 2004; 24:3-25.

Norton RK. Local commitment to state-mandated planning in coastal North Carolina. J Plann Educ Res 2005; 25(2):149-71.

Office for Official Publications of the European Communities. Guidance on EIA-EIS review; 2001. Available at http://ec.europa.eu/ environment/eia/eia-guidelines/g-review-full-text.pdf, visited on October, 20, 2007.

Pendall R. Problems and prospects in local environmental assessment: lessons from the United States. J Environ Plan Manag 1998; 41(1):5-23.

Raudsepp M. Some socio-demographic and socio-psychological predictors of environmentalism. Trames 2001; 5(55/50):355-67.

Richardson T. Environmental assessment and planning theory: four short stories about power, multiple rationality, and ethics. Environ Impact Asses Rev 2005; 25:341-65.

Scott D, Willits FK. Environmental attitudes and behavior. Environ Behav 1994; 26(2): 239-61.

Sinclair AJ, Diduck A. Public involvement in EA in Canada: a transformative learning perspective. Environ Impact Asses Rev 2001; 21:113-36.

Therivel R. Strategic environmental assessment in action. London: Earthscan; 2004. p.160.

Therrien-Richards S. SEA of Parks Canada Management Plans, ch. 10. In: Partidário MR, Clark R, editors. Perspectives in strategic environmental assessment. Boca Raton, Florida: CRC-Lewis Publishers; 2000. p. 141-54.

Treweek JR, Hankard P, Roy DB, Arnold H, Thompson S. Scope for strategic ecological assessment of trunk-road development in England with respect to potential impacts on lowland heathland, the Dartford warbler (Sylvia undata) and the sand lizard (Lacerta agilis). J Environ Manag 1998; 53(2):147-63.

Tzoumis K. Comparing the quality of draft environmental impact statements by agencies in the United States since 1998 to 2004. Environ Impact Asses Rev 2007; 27:26-40.

Tzoumis K, Finegold L. Looking at the quality of draft environmental impact statements in the United States over time: have ratings improved? Environ Impact Asses Rev 2000; 20:1-22.

Van Liere KD, Dunlap RE. Environmental concern - does it make a difference how it's measured? Environ Behav 1981; 13:651-76.

Vanderhaegen M, Muro E. Contribution of a European spatial data infrastructure to the effectiveness of EIA and SEA studies. Environ Impact Asses Rev 2005; 25(2):123-42.

Verheem R, Tonk J. Strategic environmental assessment: one concept, multiple forms. Impact Assess Proj Apprais 2000; 19(3):177-82.

Wrisberg N. Analytical tools for environmental design and management in a systems perspective: the combined use of analytical tools. Boston: Kluwer Academic; 2002. p. 20-80.

Zellmer JT, Eastman SM. Incorporation of historical aerial photographs and land-use information into environmental site assessments. Environ Eng Geosci 1997; 3(3): 431-41.

\section{Further reading}

Nitz T, Brown AL. SEA must learn how policy making works. J Environ Assess Policy Manag 2000; 3(3):329-492. 